\title{
New distal marker closely linked to the fragile $X$ locus
}

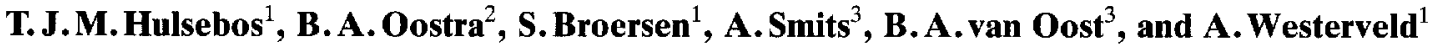 \\ ${ }^{1}$ Institute of Human Genetics, Academic Medical Centre, University of Amsterdam, Meibergdreef 15, NL-1105 AZ Amsterdam, \\ The Netherlands \\ ${ }^{2}$ Department of Cell Biology, Erasmus University, Rotterdam, The Netherlands \\ ${ }^{3}$ Department of Human Genetics, Radboud Hospital, University of Nijmegen, Nijmegen, The Netherlands
}

Received December 11,1990

Summary. We have isolated II-10, a new X-chromosomal probe that identifies a highly informative two-allele TaqI restriction fragment length polymorphism at locus DXS466. Using somatic cell hybrids containing distinct portions of the long arm of the $\mathrm{X}$ chromosome, we could localize DXS466 between DXS296 and DXS304, both of which are closely linked distal markers for fragile $\mathrm{X}$. This regional localization was supported by the analysis, in fragile $\mathrm{X}$ families, of recombination events between these three loci, the fragile X locus and locus DXS52, the latter being located at a more distal position. DXS466 is closely linked to the fragile $\mathrm{X}$ locus with a peak lod score of 7.79 at a recombination fraction of 0.02 . Heterozygosity of DXS466 is approximately $50 \%$. Its close proximity and relatively high informativity make DXS466 a valuable new diagnostic DNA marker for fragile $\mathrm{X}$.

\section{Introduction}

The fragile $\mathrm{X}$ syndrome is the most common form of inherited mental retardation (Turner et al. 1986). The incidence of this X-linked disorder is about 1 in 1500 newborn males (Webb et al. 1986). Its cytogenetic diagnosis, based on the induction of a fragile site in $\mathrm{Xq} 27.3$, is seriously hampered by frequent dissociation of the fragile $\mathrm{X}$ mutation and expression of the fragile site. For reliable carrier detection and prenatal diagnosis, cytogenetic analysis must be supplemented by DNA analysis using closely linked markers on either side of the fragile X locus. At present, the closest marker on the proximal side is DXS369 at 5\% recombination (Oostra et al. 1990). On the distal side, two closely linked markers have been identified: DXS296 without recombination (Suthers et al. 1989), and DXS304 at 2\%-5\% recombination (Vincent et al. 1989). Although favourably located, DXS296 is of limited value for diagnostic application because of

Offprint requests to: T. J.M. Hulsebos its low informativity. It is evident that, for accurate diagnosis of fragile $\mathrm{X}$ in a high percentage of families, many more closely linked informative markers need to be isolated. These markers will also be of great value for the construction of a physical map of the fragile $\mathrm{X}$ region and identification of the gene itself.

Here, we describe the isolation and characterization of a new DNA marker, DXS466, for fragile X. We have used somatic cell hybrid cell lines containing various portions of the fragile $X$ region to localize this marker with respect to the fragile locus and loci DXS296 and DXS304.

\section{Materials and methods}

Probe II-10 was derived from a cosmid library of the human $\mathrm{x}$ hamster somatic cell hybrid cell line $908 \mathrm{~K} 1$. Construction and characterization of this hybrid cell line have been described previously (Hulsebos et al. 1986). It contains a $\operatorname{der}(19 ; \mathrm{X})$ chromosome with the q24-qter part of the $\mathrm{X}$ chromosome as the only human component on a hamster background. Three cosmids from the $\mathrm{X}$ part were mixed, digested to completion with Sau3A and the resulting fragments subcloned in the Bam $\mathrm{H} 1$ site of pSP64T (Melton et al. 1984). II-10 was one of the subclones. Its 370 -bp insert was recloned in pSP65 (Promega). Other probes used in this study were VK21A and VK21C, each identifying locus DXS296 (Suthers et al. 1989), U6.2, identifying locus DXS304 (Vincent et al. 1989), and F814, identifying locus DXS52 (Heilig et al. 1988). Standard procedures were followed for the isolation of genomic DNAs, digestion with restriction enzymes, electrophoresis in agarose gels and Southern hybridization (see Sambrook et al. 1989). Alternative procedures for transfer (under alkaline conditions), hybridization (in $0.5 \mathrm{M}$ $\mathrm{NaHPO} 4$ [pH6.8], 7\% SDS, $1 \mathrm{~m} M$ EDTA) and washing (in $0.05-$ $0.1 M$ NaHPO4 [pH6.8], $1 \%$ SDS, $1 \mathrm{~m} M$ EDTA) gave equivalent results. Inserts of probes were labelled by random oligonucleotide priming according to Feinberg and Vogelstein (1984).

The human $\mathrm{x}$ hamster hybrid cell line $908 \mathrm{~K} 1 \mathrm{~B} 17$ and the human $\mathrm{x}$ mouse hybrid cell lines LC12K15 and CY34, used for the regional localization of II-10, have been described in detail previously (Schonk et al. 1989; Suthers et al. 1989, 1990; Schmidt et al. 1990).

Linkage analyses were performed with the MLINK program of the LINKAGE 5.03 package (Lathrop and Lalouel 1984), assuming a fragile $X$ (FRAXA) mutation rate of 0.0005 . Penetrance factors of 0.55 for females and of 0.8 for males were used. 


\section{Results and discussion}

Probe II-10 originates from the Xq24-qter part of an X/ 19 translocation chromosome, which is the only human chromosome in the human $\mathrm{x}$ hamster somatic cell hybrid 908K1 (Hulsebos et al. 1986). In order to find restriction fragment length polymorphisms, we hybridized this probe

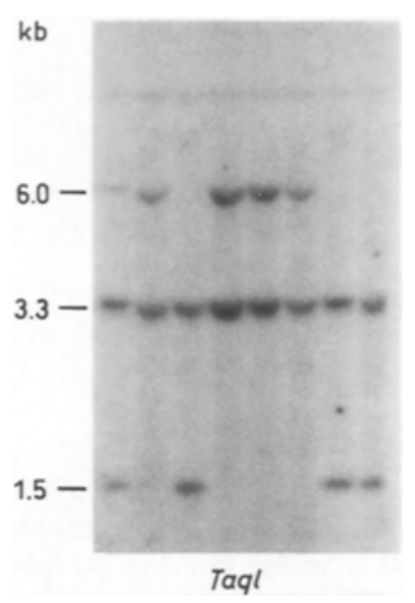

Fig. 1. Autoradiograph displaying the $T a q \mathrm{I}$ restriction fragment length polymorphism detected by probe II-10

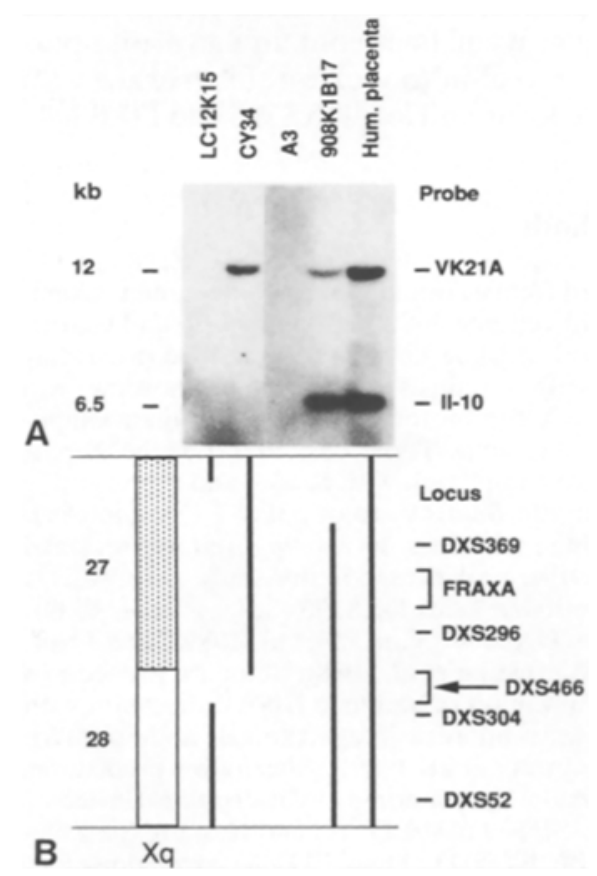

Fig. 2A, B. Regional localization of DXS466. A Southern blot analysis of $B g l I I$-digested DNAs derived from human $\mathrm{x}$ rodent somatic cell hybrid cell lines and human placenta probed with $I I-10$ and $V K 21 A$. B X chromosomal content of the hybrid cell lines and approximate positions of the fragile $\mathrm{X}$ locus (FRAXA) and the loci identified by RN1 ( $D X S 369)$, VK21A ( $D X S 296)$, U6.2 (DXS304) and F814 (DXS52). The amount of X chromosomal material from the fragile $X$ region retained in the respective cell lines is indicated by a thick line. Bracket plus arrow indicates position of DXS466 as inferred from the Southern blot analysis in $\mathbf{A}$

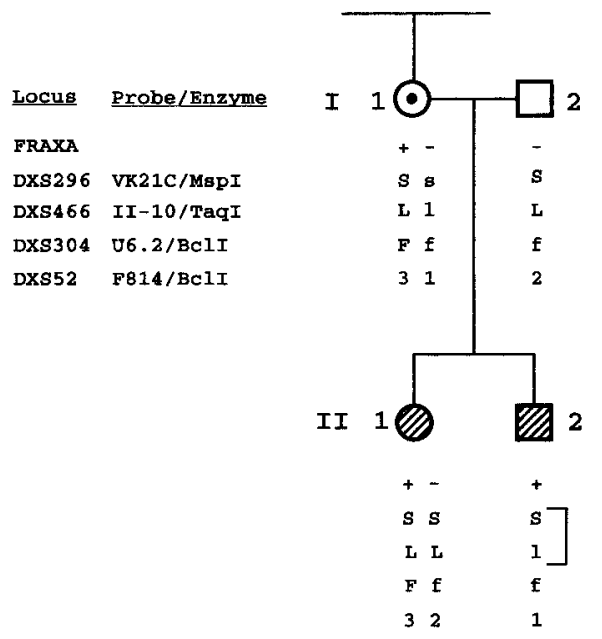

Fig. 3. Segregation analysis of DNA markers in part of a fragile $X$ family. +,- denotes presence or absence, respectively, of the fragile X mutation. Bracket indicates position of the recombination event that has occurred between DXS296 and DXS466 in this part of the family. $\odot$ Obligate carrier; mentally retarded and fragile $\mathrm{X}$ positive

to Southern blots containing sets of five genomic DNAs, digested with the restriction enzymes BamH1, BgIII, EcoRI, MspI, PvuII, PstI, RsaI, TaqI, XbaI or XmnI. Only the $T a q I$ digests displayed polymorphic fragments. They were $6 \mathrm{~kb}$ and $1.5 \mathrm{~kb}$ in length, and there was a constant band of $3.3 \mathrm{~kb}$ (Fig. 1). We estimated allele frequencies in 75 individuals and found them to be $44 \%$ for the $6-\mathrm{kb}$ allele and $56 \%$ for the $1.5-\mathrm{kb}$ allele.

Next, we determined the physical location of DXS466 in relation to the fragile $X$ locus. This was accomplished by probing human $\mathrm{x}$ rodent hybrid cell lines, containing various portions of the terminal region of Xq, with II-10. The relevant part of $\mathrm{Xq}$ and the pieces of X-chromosomal material retained in the respective cell lines, are depicted in Fig. 2B. Figure 2A shows the result of an experiment in which II-10 was hybridized to $B g l \mathrm{II}$ digests of genomic DNAs derived from the cell lines. As an internal control, we probed the blot simultaneously with VK21A. This probe hybridizes with a $B g I I I$ fragment of approximately $12 \mathrm{~kb}$ that is present in cell lines $908 \mathrm{~K} 1 \mathrm{~B} 17$ and CY34 but that is absent both in cell line LC12K15 and in a hamster-only cell line (A3). This hybridization pattern is in accordance with earlier observations of Suthers et al. (1990). Probe II-10 only reacts with $6.5-\mathrm{kb}$ fragment in cell line 908K1B17. We conclude from the absence of hybridization of II-10 with LC12K15 and CY34 that DXS466 is located in the region (indicated in Fig. 2B) that is absent in both cell lines. This places DXS466 on the distal side of the fragile X locus between DXS296 and DXS304.

We found support for the physical localization of DXS466 by the analysis of individual recombination events in fragile $X$ families. Figure 3 shows the segregation of the alleles detected by probes VK21C, II-10, U6.2 and F814 in one branch of a large fragile X family. The coupling phase in I-1 was infered from analysis of the other part of this family (data not shown). VK21C 
Table 1. Two-point lod scores $(\hat{Z})$ at various recombination fractions $(\hat{\theta})$ for linkage of DXS466 with the fragile X locus (FRAXA) and other loci

\begin{tabular}{|c|c|c|c|c|c|c|c|c|c|}
\hline \multirow[t]{2}{*}{ Loci } & \multicolumn{7}{|c|}{ Recombination fraction } & \multirow[t]{2}{*}{$\hat{z}$} & \multirow[t]{2}{*}{$\hat{\theta}$} \\
\hline & 0.001 & 0.01 & 0.05 & 0.10 & 0.20 & 0.30 & 0.40 & & \\
\hline DXS466-FRAXA & 7.02 & 7.69 & 7.60 & 6.91 & 5.14 & 3.18 & 1.29 & 7.79 & 0.02 \\
\hline DXS466-DXS304 & 4.39 & 4.31 & 3.96 & 3.52 & 2.60 & 1.63 & 0.68 & 4.40 & 0 \\
\hline DXS466-DXS52 & 1.13 & 4.00 & 5.50 & 5.60 & 4.75 & 3.33 & 1.64 & 5.64 & 0.08 \\
\hline
\end{tabular}

cosegregates with fragile $\mathrm{X}$, whereas recombination must have occurred between II-10 and fragile X, and also between the other two probes and fragile $X$. These results support the physical positioning of DXS466 distal to DXS296. In our fragile X families, we found no recombinations between DXS466 and DXS304. Thus, DXS466 could not be positioned relative to DXS304 by this type of analysis. On the other hand, in two families with recombinations between F814 (identifying locus DXS52) and fragile $X$, we found cosegregation of II-10 with the disease locus (data not shown). We conclude from the latter observations that DXS466 occupies a proximal position relative to DXS52.

We determined two-point lod scores for linkage of DXS466 with the fragile X locus (FRAXA), DXS296, DXS304 and DXS52 in 15 fragile X families. Two of these are 2-generation families, the others have 3 (or more) generations. A total of 166 persons, of whom 49 were fragile $\mathrm{X}$-positive and/or mentally retarded, were typed with the probes identifying the respective marker loci. The results are summarized in Table 1. Lod scores for linkage of DXS466 with DXS296 were low (less than 1) because of a lack of informative meioses and were therefore not included in the Table. We calculated a peak lod score of 7.79 at a recombination fraction of 0.02 for linkage of DXS466 with the fragile X locus. The approximate $90 \%$ confidence limits for the recombination fraction (Conneally et al. 1985) were 0 and 0.11 . In practice, considering the physical localization of DXS466 proximal to DXS304, we use an upper limit recombination fraction of 0.05 , i.e. the upper limit recombination fraction for DXS304 (Vincent et al. 1989), in risk calculations involving DXS466. As stated before, in the genetic analyses of our fragile $X$ families, we found no recombinations between DXS466 and DXS304, resulting in a peak lod score of 4.40 at recombination fraction 0 (Table 1). The observed recombination fraction for linkage between DXS466 and DXS52 (0.08, see Table 1$)$ is in accordance with that expected (0.07-0.12), based on published figures (Brown et al. 1988; Vincent et al. 1989) and the assumption that DXS466 is located between DXS296 and DXS304.

In summary, we localized DXS466 by physical mapping between DXS296, the closest distal marker for fragile $X$, and DXS304. This assignment was supported by genetic mapping data obtained from the analysis of 15 fragile $\mathrm{X}$ families. DXS466 is closely linked to the fragile $\mathrm{X}$ locus and has a heterozygosity of almost $50 \%$. In our family material, DXS466 was approximately 3 times more informative than DXS296. This makes DXS466 a valuable new distal marker and informative alternative for DXS296 in the DNA diagnosis of fragile $\mathrm{X}$.
Acknowledgements. We thank Drs. G. R. Sutherland, N. Dahl, and J.-L. Mandel for giving us permission to use probes VK21A/VK21C, U6.2, and F814, respectively. We are grateful to Professor H.H. Ropers for the use of cell line $908 \mathrm{~K} 1 \mathrm{~B} 17$, Dr. M. Schmidt for the use of cell line LC12K15, and Dr.D.F. Callen for the use of cell line CY34. We thank J. Dreesen for expert technical assistance and R. Lutgerhorst for the artwork. We would also like to thank the genetic counsellors and cytogeneticists in Amsterdam, Rotterdam and Nijmegen for collecting pedigree information and for performing the cytogenetic analyses.

\section{References}

Brown WT, Gross A, Chan C, Jenkins EC, Mandel JL, Oberlé I, Arveiler B, Novelli G, Thibodeau S, Hagerman R, Summers K, Turner G, White BN, Mulligan L, Forster-Gibson C, Holden JJA, Zoll B, Krawczak M, Goonewardena P, Gustavson $\mathrm{KH}$, Pettersson U, Holmgren G, Schwartz C, Howard-Peebles PN, Murphy P, Breg WR, Veenema H, Carpenter NJ (1988) Multilocus analysis of the fragile $\mathrm{X}$ syndrome. Hum Genet 78 : 201-205

Conneally PM, Edwards JH, Kidd KK, Lalouel JM, Morton NE, Ott J, White R (1985) Report of the committee on methods of linkage analysis and reporting. Cytogenet Cell Genet 40:356359

Feinberg AP, Vogelstein B (1984) A technique for radiolabeling DNA restriction endonuclease fragments to high specific activity. Addendum. Anal Biochem 137:266-267

Heilig R, Oberlé I, Arveiler A, Hanauer A, Vidaud M, Mandel JL (1988) Improved DNA markers for efficient analysis of fragile $X$ families. Am J Hum Genet 30:543-550

Hulsebos T, Wieringa B, Hochstenbach R, Smeets D, Schepens J, Oerlemans F, Zimmer J, Ropers H-H (1986) Toward early diagnosis of myotonic dystrophy: construction and characterization of a somatic cell hybrid with a single human der(19) chromosome. Cytogenet Cell Genet 43:47-56

Lathrop GM, Lalouel J-M (1984) Easy calculations of lod scores and genetic risks on small computers. Am J Hum Genet 36: 460-465

Melton DA, Krieg PA, Rebagliati MR, Maniatis T, Zinn K, Green MR (1984) Efficient in vitro synthesis of biologically active RNA and RNA hybridization probes from plasmids containing a bacteriophage SP6 promoter. Nucleic Acids Res 12:7035-7056

Oostra BA, Hupkes PE, Perdon LF, Van Bennekom CA, Bakker E, Halley DJJ, Schmidt M, Du Sart D, Smits A, Wieringa B, Van Oost BA (1990) New polymorphic DNA marker close to the fragile site FRAXA. Genomics 6:129-132

Sambrook J, Fritsch EF, Maniatis T (1989) Molecular cloning: a laboratory manual, 2nd edn. Cold Spring Harbor Laboratory, Cold Spring Harbor, NY

Schmidt M, Certoma A, Du Sart D, Kalitsis P, Leversha M, Fowler K, Sheffield L, Jack I, Danks DM (1990) Unusual X chromosome inactivation in a mentally retarded girl with an interstitial deletion $\mathrm{Xq} 27$ : implications for the fragile $\mathrm{X}$ syndrome. Hum Genet 84:347-352

Schonk D, Coerwinkel-Driessen M, Van Dalen I, Oerlemans F, Smeets B, Schepens J, Hulsebos T, Cockburn D, Boyd Y, Davis $M$, Rettig W, Shaw D, Roses A, Ropers H, Wieringa B 
(1989) Definition of subchromosomal intervals around the myotonic dystrophy gene region at 19q. Genomics 4:384-396

Suthers GK, Callen DF, Hyland VJ, Kozman HM, Baker E, Eyre H, Harper PS, Roberts SH, Hors-Cayla MC, Davies KE, Bell MV, Sutherland GR (1989) A new DNA marker tightly linked to the fragile X locus (FRAXA). Science 246:1298-1300

Suthers GK, Hyland VJ, Callen DF, Oberlé I, Rocchi M, Thomas NS, Morris CP, Schwartz CE, Schmidt M, Ropers H-H, Baker E, Oostra BA, Dahl N, Wilson PJ, Hopwood JJ, Sutherland GR (1990) Physical mapping of new DNA probes near the fragile X mutation (FRAXA) by using a panel of cell lines. Am J Hum Genet 47:187-195
Turner G, Opitz JM, Brown WT, Davies KE, Jacobs PA, Jenkins EC, Mikkelsen M, Partington MW, Sutherland GR (1986) Conference report: 2nd International Workshop on the Fragile $\mathrm{X}$ and on X-linked Mental Retardation. Am J Med Genet 23: $11-67$

Vincent A, Dahl N, Oberlé I, Hanauer A, Mandel JL, Malmgren H, Pettersson U (1989) The polymorphic marker DXS304 is within 5 centimorgans of the fragile X locus. Genomics 5:797801

Webb TP, Bundey SE, Thake AI, Todd J (1986) Population incidence and segregation ratios in Martin-Bell syndrome. Am $\mathbf{J}$ Hum Genet 23:573-580 